\title{
IONIC CHANNELS IN PLANTS: POTASSIUM TRANSPORT
}

\author{
CANAIS IÔNICOS EM PLANTAS: O TRANSPORTE DE POTÁSSIO
}

\author{
Antonio Costa de Oliveira ${ }^{1}$
}

\section{- REVIEW -}

\section{SUMMARY}

The discovery of potassium channels on the plasma membrane has helped to elucidate important mechanisms in animal and plant physiology. Plant growth and development associated mechanisms, such as germination, leaf movements, stomatal action, ion uptake in roots, phloem transport and nutrient storage are linked to potassium transport. Studies describing potassium transport regulation by abscisic acid (ABA), $\mathrm{Ca}^{++}$, light and other factors are presented here. Also the types of channels that regulate potassium uptake and efflux in the cell, and the interaction of these channels with external signals, are discussed.

Key words: ionic channels, potassium channels.

\section{RESUMO}

A descoberta de canais iônicos presentes na membrana plasmática tem ajudado a elucidar importantes mecanismos fisiologicos em animais e plantas . Mecanismos associados ao crescimento e desenvolvimento das plantas, tais como germinação, movimento foliar, abertura e fechamento de estômatos, absorção de íons pelas raízes e armazenamento de nutrientes estāo ligados ao transporte de potássio. Estudos descrevendo a regulação do transporte deste nutriente por ácido abscísico (ABA), $\mathrm{Ca}^{++}$, luz e outros fatores são apresentados. Os tipos de canais que regulam a saída e entrada de potássio na célula, e as interaçôes destes com os sinais externos, são discutidos.

Palavras-chave: canais iônicos, canais de potássio:

\section{INTRODUCTION - IONIC CHANNEIS}

Membranes of living cells have the property to maintain metabolic and ionic gradients that are necessary for growth, development, and movement in the cells. Acting as barriers, these nembranes have some gates (channels) which can be activated to accelerate the flow of solutes or messengers across them (HEDRICH \& SCHROEDER, 1989).

Membrane transport proteins can mediate either active transport, in wich energy is used to move molecules across the membrane, or passive transport, in which molecules cross the membrane without expending energy-rich compounds. lonic channels can mediate either active or passive transport and are defined as transmembrane proteins that can undergo many different conformational states. When the conformation is arranged in such a way that the protein core forms a pathway for diffusion, the channel is in the open state. Studies with animal cells showed that various stimuli, including appropriate voltage, light, specific hormones, or

\footnotetext{
1 MSc., Professor Assistente do Departamento de Fitotecnia, Centro de Ciéncias Rurais, Universidade Federal de Santa Maria. Present address: Department of Biological Sciences, Purdue University, 47907, West Lafayetle, IN, USA.

Received for publication: August 04, 1993. Approved: October 25, 1994.
} 
increase in intracellular $\mathrm{Ca}^{++}$, can increase the frequency of opening and/or the duration of the open state by several orders of magnitude.

The reasons why we should study the molecular mechanisms by which plants transport and accumulate potassium across the plasma membrane rely on the importance of these mechanisms to our understanding of plant nutrition and growth. As plant breeders and plant physiologists search for more efficient crops and for ways to maximize plant metabolism, many of the needed answers will come from the study of ionic channels.

\section{CURRENT METHODOLOGY USED TO STUDY IO- NIC CHANNEIS}

A major breakthrough for studies of ionic channels was the discovery of the patch clamp technique (NEHER \& SAKMANN, 1976). Patch clamp methods permit the identification of single ion-specific channels in the plasmalemma, tonoplast, or organelllar outer membranc. In these experiments, a glass eletrode with a tip diameter of ca. 1.0 micrometers is brought into contact with the outer membrane of an isolated wall-less cell (a protoplast), an isolated vacuole, or some other isolated sub cellular compartment. Slight suction is then applied to aid in forming a tight (high resistance) seal between the electrode and the membrane. This is the cell-attached or on-cell configuration. The pipette can be withdrawn from the cell so that only a small membrane patch remains intact within the tip (inside-out patch). Alternatively, after the patch within the rim of the pipette may be ruptured, forming the whole-cell configuration. If the pipette is now withdrawn, the membrane tears and some of it, outside the pipette, reseals over the tip (outside-out patch). With these different scenarios, one can study the effects of transmembrane voltage, light, hydrostatic pressure, and various chemical compounds on the kinetics of gating of single channels.

\section{POTASSIUM CHANNEIS}

Potassium is a very important nutrient in plants and its transport across the plasma membrane of plant cells is closely linked to diverse actions taking place in cells and tissues. Plant growth and development associated mechanisms, such as germination, leaf movements, stomatal action, ion uptake in roots, phloem transport and nutrient storage are closely linked to the transport of this nutrient (HEDRICH \& SCHROEDER, 1989).

The first studies suggesting the existence of $\mathrm{K}^{+}$ channels in the plasma membrane is at least partly respon- sible for membrane repolarization during the action potential (TESTER, 1990).

Two classes of $\mathrm{K}^{+}$channels, strongly regulated by the membrane potential, were characterized in guard cells. These channels were designated $\mathrm{I}_{\mathrm{K}}{ }^{+}$out channels for $\mathrm{K}^{+}$efflux (outward-rectifying channels) and $\mathrm{I}_{\mathrm{K}}+$ in channels for $\mathrm{K}^{+}$uptake (inward-rectifying channels), as described by SCHROEDER (1988).

SCHROEDER \& HAGIWARA (1990) suggested an effect of calcium flux into the cytosol of guard cells as a major factor in the induction of stomatal closing by abscisic acid (ABA). ABA closes stomatal pores, thereby reducing transpirational loss of water by plants under drought conditions. In responsive guard cells, external exposure to ABA produced transient repetitive increases in the cytosolic free $\mathrm{Ca}^{++}$concentration. The modulation of voltage-depedent anion channels by cytosolic $\mathrm{Ca}^{++}$and the resulting activation of outward conducting $\mathrm{K}^{+}$channels have been suggested by SCHROEDER \& HAGIWARA (1989) as providing a molecular basis for the $\mathrm{Ca}^{++}$dependence of $\mathrm{ABA}$-induced stomatal closure.

A substrate regulation of potassium and chloride channel conductance was proposed by LEW (1991), using inside-out patches of protoplast plasma membranes of $\boldsymbol{A}$. thaliana. The author suggests that the potassium channel is regulated by substrate $(\mathrm{KCl})$ as a consequence of its molecular architecture as a multi-ion pore. By contrast, the chloride channel exhibits a concave upward change in conductance with increasing cytoplasmic-side $(\mathrm{KCl})$ that can best be explained as an allosteric effect. It was suggested that a binding site for $\mathrm{K}^{+}$or $\mathrm{Cl}^{-}$separate from the chloridespecific pore regulates the conductance of the pore. Another study (LEW et al., 1990) showed that phytochrome activates one or two $\mathrm{K}^{+}$channel(s) wich are also activated by elevating cytosolic calcium with A2317 (a calcium ionophore).

SCHROEDER \& FANG (1991) suggested that inward-rectifying $\mathrm{K}^{+}$channels in higher plants provide an important mechanism for low-affinity $\mathrm{K}^{+}$uptake and noted that small $\mathrm{K}^{+}$efflux currents recorded at low extracellular $\mathrm{K}^{+}$concentrations may be sufficient to contribute to hyperpolarization. This hyperpolarization may stimulate high-affinity $\mathrm{K}^{+}$uptake transporters, thus contributing to $\mathrm{K}^{+}$ uptake at low extracellular $\mathrm{K}^{+}$concentrations.

Two highly distinct types of depolarizationactivated anion currents that operate in the plasma membrane of Vicia faba guard cells were described by SCHROEDER \& KELLER (1992). One type was activated rapidly within $50 \mathrm{~ms}$ by depolarization, inactivated during prolonged stimulation, and deactivated rapidly at hyperpolarized potentials (R-type anion current). The other type showed extremely slow voltage-dependent activation and deactivation (S-type anion current) and lacked inactivation. The authors suggest that the $R$-type of anion 
channels contribute to regulation of other processes during stomatal movements which require transient depolarization, being the S-type the major mechanism in controlling ion efflux and the resulting closing of stomata.

Three $\mathrm{K}^{+}$channels were found in Arabidopsis thaliana leaf mesophyll cells by SPALDING et al. (1992). Using inside-out patches, they described that two channels, were selective for $\mathrm{K}^{+}$over $\mathrm{Na}^{+}$and $\mathrm{Cl}^{-}$. The first, named $\mathrm{PKC}_{1}$, had a maximum conductance (Gmax) of 44 picosiemens at a membrane voltage $(\mathrm{Vm})$ of $-65 \mathrm{mV}$ in 220 $\mathrm{mMK}^{+}$on the cytoplasmic side of the patch and $50 \mathrm{mM} \mathrm{K}^{+}$ in the pipette $(220 / 50 \mathrm{~K})$ and is stimulated by light. The other $\left(\mathrm{PKC}_{2}\right)$ had $\mathrm{Gmax}=66$ picosiemens at $\mathrm{Vm}=60 \mathrm{mV}$ in $(220 / 50 \mathrm{~K})$. The third channel type $\left(\mathrm{PCC}_{1}\right)$ transported $\mathrm{K}^{+}$ and $\mathrm{Na}^{+}$equally well but not $\mathrm{Cl}^{\circ}$. It had $\mathrm{Gmax}=109$ picosiemens at $\mathrm{Vm}=55$ millivolts in $(250 / 50 \mathrm{~K})$ with 10 $\mathrm{mM} \mathrm{Ca}^{++}$on the cytoplasmic side. Reducing $\mathrm{Ca}^{++}$to $0.1 \mathrm{mM}$ increased $\mathrm{PCC}_{1}$ open-channel currents by approximately $50 \%$ in a voltage-independent manner. An effect caused by reductants ( $1 \mathrm{mM}$ dithiothreitol or $10 \mathrm{mM}$ B-mercaptoethanol) was observed. When added to the cytoplasmic side of an excised patch they increased the open probability of all three channel types. It was suggested that light may exert its effects on $V m$ and channels via photosynthesis by producing diffusible reductants. The reducible sites in the membrane that affect channel activity may be sulphydril groups on the channel proteins.

Light-induced stromal alkalinization, and the subsequent maintenance of high stromal $\mathrm{pH}$ in the light, is an important regulatory phenomenon that enables the functioning of enzymes of the photosynthetic pathways (Werdam et al. apud WU \& BERKOWITZ, 1992). The linkage between $\mathrm{K}^{+}$and the maintenance of this high stromal pH was studied by WU \& BERKOWITZ (1992) who showed that $\mathrm{K}^{+}$uniport in either direction across the chloroplast envelope is facilitated by an envelope $\mathrm{K}^{+}$efflux through this channel provides the electrical driving force for $\mathrm{H}^{+}$counterflux (which likely occurs through a distinct, $\mathrm{H}^{+}$ uniport pathway), and that $\mathrm{K}^{+}$efflux through this channel has a substantial effect on photosynthesis indirectly, due to stromal acidification.

Some of the $\mathrm{K}^{+}$channel genes give rise to multiple protein products because of alternative splicing thereby further increasing the diversity of $\mathrm{K}^{+}$channels. Other consideration for the generation of $\mathrm{K}^{+}$channel diversity include the assembly of $\mathrm{K}^{+}$channel subunits encoded by different genes or differentially spliced transcripts. Voltage-gated $\mathrm{K}^{+}$channel polypeptides contain a hydrophobic core region that includes several potentia' membrane spanning segments and is tlanked by two hydrophilic cytoplasmic domains. LI et ai : 1992) suggested that the diversity found in Drosophila and other speces (Shaker, Shab, Shaw and Shal K' (hannels) could be a case of coassembling of different types of $\mathrm{K}^{+}$channel polypeptides forming heteromultimeric channels with distinct properties, investigating the $\mathrm{K}^{+}$channel subunit interactions, these authors proposed that the subunit interactions that support $\mathrm{K}^{+}$channel assembly involve the hydrophilic $\mathrm{NH}_{2}$-terminal domain as well as the hydrophobic core region. The interactions involving the $\mathrm{NH}_{2}$-terminal domain are homophilic so that a tetramer of $\mathrm{NH}_{2}$-terminal domains forms at the cytoplasmic side of the membrane end of the channel pore. The minimal structural element required for the homophilic interaction of the ShB $\mathrm{NH}_{2}$-terminal domain is a 114-amino acid fragment. This structural element separates the cytoplasmic inactivation gate from the structural elements associated with the voltage sensor, the pore-lining structures, and the receptor for the inactivation gate at the cytoplasmic mouth of the pore. No indications of any involvement of the hydrophilic $\mathrm{COOH}$-terminal domains in the subunit interaction have been obtained. It was suggested that the $\mathrm{K}^{+}$channel molecule could form a roughly cylindrical structure that extends from the membrane into the cytoplasm.

Regulation by $\mathrm{G}$-protein of inwardly rectifying $\mathrm{K}^{+}$ channels was showed by FAIRLEY-GRENOT \& ASSMANN (1991). The activation of the G-protein involved was shown to result in a decrease in inward $\mathrm{K}^{+}$ current.

In general, animal studies are ahead of plant studies in this area. In this case, it is important for plant physiologists to be well informed about the new developments in the animal science literature, in order to have more basis to interpret novel phenomena occuring in plants.

\section{CONCI,USION AND PERSPECTIVES}

The regulation of potassium channels involves a complex interaction of environment signals and multiple regulatory mechanisms. The action of light, Cat+, GTP binding proteins described here may act together with additional participation of proton ATPases, anion channels and $\mathrm{Ca}^{++}$permeable channels.

Perhaps animal systems, as Xenopus oocytes, will h. Ip to enhance our knowle lge of the molcicular structure of 1 .. proteins (channels) in $y^{\prime \cdot n t s . ~ T h i s ~ s t u a t i o n ~ h a s ~ b e e n ~}$ siudles by CAO et ai.. (1., ', slicatid a an

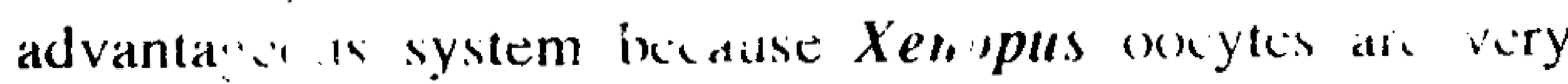
large and thus suitable for nicroinjection. whage-clan. ing,

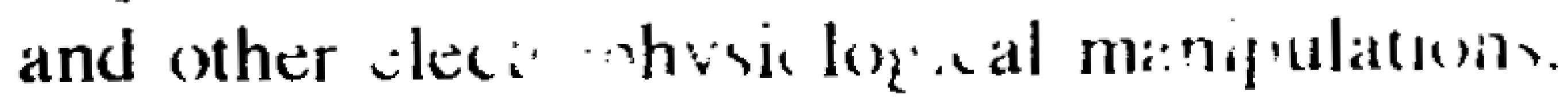

A lo, of ethirs has been made to understand the $\mathrm{K}^{+}$regulation phenomina and as more advanced combinations of mole sular brology and plant physiology techniplics are developed, it seems likely that tie answers to the phomom. na will conce soon. 


\section{ACKNOWLEDGEMENTS}

The author is thankful to the conselho Nacional die Desenvolvimento (ient ifico a Tecnologico (CNPq), and to the Iniversidade Federal de Santa Maria lor the PhD fellowship and suppont received.

\section{REFERENCFS}

(AO, Y., ANDEROVAM, M., (RAWFORD, N,M., et al. Expression of an outward-rectifying polassium channel from maize mRNA in Xenopus cocytes The Plant Cell, v. 4, p. 961-969, 1992.

FAIRLEY-GRENOT, K., ASSMANN, S.M. Evidence for G-protein regulation of inward $K+$ channel current in guard cells of fava bean. The Plant cell, v. 3, p. 1037-1044, 1991

HEDRICH, R., SCHROEDER, J.L. The physiology of ion chancls and electrogenic pumps in higher plants. Annu Rev Plant Physiol, v. 40, p. $539-569,1989$.

LEW, R.R. Substrate regulation of single polassium and chloride ion channels in Arabidopsis plasma membranc. Plant Physiol., v. 45, p. $642-647,1991$.

LEW, R.R., SERLIN, B.S., SCHAIF, C.L., al al. Red light regulates calcium-activated potassium channels in Mougeotia plasma membranc Plant Physiol, v. 92, p. 822-8.30, 1990.

LI, M., JAN, Y,N., JAN, L,Y. Specification of subunit assimbly by the hydrophylic amino-lerminal domain of the shaker potassium channel. Science, v. 257, p. 1225-1230, 1942.
NEHER, E., SAKMANN. B. Single-channd currents recorded fiom membanc of denervated frog muscle fibers. Nature, v. 260, p. 779 . 802,1976

S( 'HROEDER, J.I. K' tallspont properties of $\mathrm{K}$ channels in the plasm.t membranc of Vicia faba guard cells. J Cien Physiol, v. 92. p. 667-68.3. 1488

S( 'HR()EDER, J.I., FAN( ;, H.H. Inward rectitying $\mathbf{K}$ ' channels in guard cells provide a mechanism lor low-affinity $\mathrm{K}^{\prime \prime}$ uptake. Proc Natl Acad Sici, v. 88, p. 11583-11587, 1941

S( 'HRODER, J.I., KELLER, B.U. Two types of anion chantel curents in guard cells with distinet voltage regulation. Proc Natl Acad Sci, v. 84. p.5025-5029, 1992

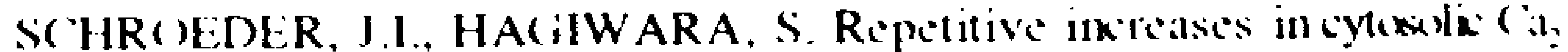
of guand cells by abse isic acid activation of moneledive (at permeable chanmels. Proc Natl Acad Sci, v. 87, p. 9.305-4.3(59, 1940).

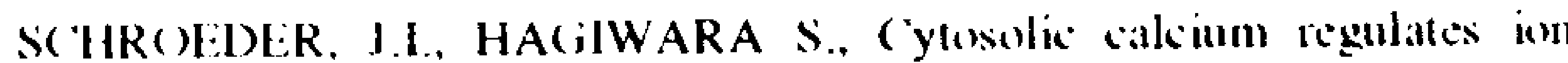
chamkels in the plasma membrane of Vicia faba guard cells. Nature, $v$ 3.38, p. $+27+430.1984$

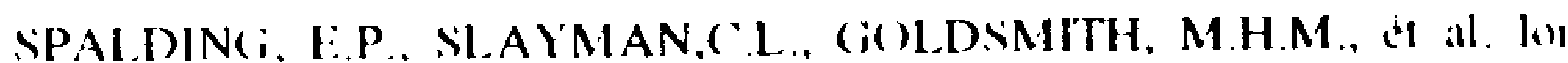
chanuels in Arabidopsis plama membranc. Plant Pliysiol, v. 29, p. y6 10. $1(x)$.

THEItR, M. Plant ion chamels: whols cell and single-chanmel studies New Phytol, v. 114, p. 305-340, 1490.

WU, W. BH:RKoWITZ, (i.A. Stromal pH and phomsynthesis are aflected

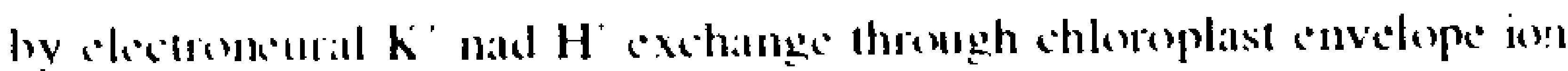
chammels. l'lant Plivsiol, v. 98, p. 666.672, 1942. 